\title{
DAMPAK BLENDED LEARNING PADA MATERI FLUIDA DINAMIS TERHADAP HASIL BELAJAR SISWA
}

\author{
Tarissa Niswatun Aunillah*, Wayan Suana, I Wayan Distrik \\ FKIP Universitas Lampung, Jl. Prof. Dr. Soemantri Brojonegoro No.1 \\ *email: tarissaniswatun@gmail.com
}

Received: 4 Juni 2018 Accepted: 8 Juni 2018 Online Published: 8 Juni 2018

\begin{abstract}
The Effect of Blended Learning On Dynamic Fluid Topic to Student Learning Achievement. This study aims to describe the effect of blended learning on dynamic fluid topic to student learning achievement. This research was conducted at one of Senior High School in Bandarlampung with the Quasi-Experimental design pretest-posttest control group. Data were tested using N-Gain analysis, normality test, homogeneity test and Independent Sample T-Test. Results from the Independent Sample T-Test Sig value. (2-Tailed) less than 0.05 is 0.000, then it can be stated there is a differences on increasing of student learning achievement who learned using Learning Management System (LMS) based blended learning device with scientific approach and students who learned using expository method. LMS based blended learning device with scientific approach on dynamic fluid topic can improve student learning achievement in the cognitive domain with $N$-Gain in the experimental class is 0.72 (high category), while the control class is 0.49 (medium category).
\end{abstract}

Keywords: Blended Learning, Dynamic Fluid, Learning Achievement

\begin{abstract}
Abstrak: Dampak Blended Learning Pada Materi Fluida Dinamis Terhadap Hasil Belajar Siswa. Penelitian ini bertujuan untuk mendeskripsikan efektivitas blended learning pada materi fluida dinamis terhadap hasil belajar siswa. Penelitian ini dilakukan di salah satu SMA di Bandarlampung dengan menggunakan desain penelitian Quasi Experimental pretest-posstest control group design. Data hasil penelitian diuji dengan analisis $N$-Gain, uji normalitas, uji homogenitas, dan independent sample t-test. Hasil uji nilai independent sample t-test nilai Sig. (2Tailed) kurang dari 0,05 yaitu 0,000, maka dapat dinyatakan terdapat perbedaan peningkatan hasil belajar antara siswa yang belajar menggunakan blended learning berbasis Learning Management System (LMS) dengan pendekatan ilmiah dan siswa yang belajar menggunakan metode ceramah. Blended learning berbasis $L M S$ dengan pendekatan ilmiah pada materi fluida dinamis mampu meningkatkan hasil belajar siswa pada ranah kognitif dengan rata-rata nilai $\mathrm{N}$-Gain kelas eksperimen sebesar 0,72 dengan kategori tinggi, dan rata-rata nilai $N$-Gain kelas kontrol sebesar 0,49 dengan kategori sedang.
\end{abstract}

Kata kunci: Blended Learning, Fluida Dinamis, Hasil Belajar 


\section{PENDAHULUAN}

Pada abad 21, teknologi informasi dan komunikasi (TIK) berkembang dengan sangat pesat. Perkembangan teknologi yang demikian pesat tentunya membawa pengaruh dan dampak positif terhadap berbagai aspek kehidupan manusia, tak terkecuali dalam bidang pendidikan. Perkembangan TIK dapat di implementasikan dalam bidang pendidikan untuk meningkatkan mutu pendidikan. Menghadapi hal ini, guru dituntut untuk mampu merancang desain pembelajaran yang menyesuaikan dengan tuntutan pembelajaran abad 21. Guru dapat memanfaatkan TIK dalam pembelajaran seperti pemanfaatan internet. Perkembangan TIK khususnya perkembangan teknologi komputer dengan internet, berpengaruh terhadap berkembangnya konsep pembelajaran jarak jauh (Munir, 2009: 17). Pada kenyataannya saat ini, masih banyak guru yang kurang maksimal dalam megimplementasian TIK dalam pembelajaran, contohnya terjadi di salah satu SMA di Bandarlampung. Pada umumnya, guru menggunakan TIK terutama internet hanya digunakan sebagai sumber untuk mencari bahan pembelajaran. Dengan adanya internet, para siswa juga dituntut untuk belajar mandiri dalam mencari dan menggali informasi. Informasi tidak hanya didapat dari guru saja tetapi juga dari media internet, sehingga dapat meningkatkan keefektivan dan efisiensi belajar siswa.

Berdasarkan hasil wawancara yang diperoleh dengan salah satu guru fisika di salah satu SMA di Bandarlampung bahwasannya pada proses pembelajaran fisika guru belum memanfaatkan TIK dalam pembelajaran dan pembelajaran yang digunakan masih dengan metode ceramah yang cenderung berpusat pada guru (teacher centered). Pembelajaran ceramah membuat siswa cepat merasa jenuh dan pasif di dalam kelas. Fitriyadi (2013) menyatakan bahwa keterampilan belajar mengajar abad ke-21 menggarisbawahi kebutuhan untuk beralih dari metode yang berpusat pada guru untuk lebih berpusat pada siswa (student centered learning). Keterampilan pembelajaran abad 21 juga menuntut siswa untuk terlibat langsung dalam proses pembelajaran sehingga siswa aktif mencari tahu informasi dari berbagai sumber melalui observasi, siswa dapat memecahkan masalah sendiri dan mampu mengonstruksi pengetahuannya berdasarkan fakta-fakta yang ditemukan di lapangan.

Masalah pembelajaran lain yang dikemukakan guru saat wawancara yaitu siswa mengganggap bahwa materi fluida dinamis cukup sulit karena siswa mengalami kesulitan mengerjakan soal-soal tentang materi fluida dinamis. Selain itu, kurangnya alokasi waktu pembelajaran di dalam kelas yang menyebabkan tidak semua materi dapat disampaikan guru dan hanya beberapa tujuan pembelajaran yang dapat tercapai. Hal ini dapat berakibat pada hasil belajar siswa yang rendah, sehingga diperlukanlah model pembelajaran yang dapat mengatasi permasalahan ini.

Salah satu inovasi pembelajaran yang menyesuaikan dengan perkembangan TIK, pembelajaran yang berpusat pada siswa dan mampu mengatasi kesulitan-kesulitan belajar siswa adalah model pembelajaran blended learning. Munculnya suatu pembelajaran melalui media elektronik atau yang biasa disebut e-learning yaitu pembelajaran yang memanfaatkan internet maka sistem pembelajaran tidak melalui tatap muka saja. Melalui kemajuan teknologi ini, guru dan siswa tidak perlu menunggu waktu tertentu atau pergi ke tempat tertentu untuk 
belajar, sehingga siswa dapat belajar kapan saja, dimana saja, dengan siapa saja.

Mosa (2006) menyatakan bahwa blended learning adalah kombinasi dua unsur utama pembelajaran, yakni pembelajaran di kelas dengan tatap muka dan pembelajaran secara online. Tipe blended learning yang digunakan pada penelitian ini yaitu online-tatap muka. Blended learning memiliki ba-nyak kelebihan, terbukti dari beberapa hasil penelitian terdahulu. Berdasarkan hasil penelitian Sjukur (2012) me-nunjukkan hasil yaitu siswa yang mengikuti pembelajaran dengan blended learning memiliki peningkatan motivasi dan prestasi belajar yang lebih tinggi dibandingkan dengan siswa yang diajarkan menggunakan metode pembelajaran ceramah. Hal ini sesuai dengan penelitian Poon (2013).

Untuk dapat menerapkan model pembelajaran blended learning dibutuhkan suatu software atau perangkat program. Salah satu software yang dapat digunakan adalah Learning $\mathrm{Ma}$ nagement System (LMS). Ada beberapa jenis $L M S$ yang biasanya digunakan dalam proses pembelajaran diantaranya yaitu schoology, learnboos, edmodo, moodle, dan lain-lain. LMS yang digunakan pada penelitian ini yaitu schoology. Amiroh (2013) menyatakan bahwa jika dibandingkan dengan $L M S$ yang lain schoology menggunakan istilah-istilah yang biasa kita gunakan pada jejaring sosial facebook, twitter, moddle, dan edmodo seperti recent activity, message, course, resource, groups, assignment, dan attendance. Schoology memiliki fasilitas-fasilitas yang tidak dimiliki oleh edmodo dan moddle.

Berdasarkan hal ini, siswa dapat memanfaatkan media online untuk pembelajaran dan tidak hanya menggunakan media sosialnya saja. Schoo- logy juga mempermudah siswa karena fitur dan istilah yang digunakan sudah biasa ditemukan siswa pada media sosialnya. Hasil penelitian yang dilakukan oleh Suana dkk. (2017) menyatakan bahwa pembelajaran blended learning yang dilaksanakan melalui schoology dapat meningkatkan minat dan motivasi belajar siswa, serta dapat mengembangkan keterampilan TIK siswa. Selain itu, pemberian latihan soal pada schoology membuat siswa dapat latihan secara mandiri untuk dapat meningkatkan pemahaman konsep siswa dan keterampilan pemecahan masalah. Hal ini sejalan dengan penelitian Utami dkk. (2017) yang menunjukkan bahwa pembelajaran menggunakan e-learning dengan schoology memiliki pengaruh signifikan terhadap hasil belajar siswa.

Pada penelitian ini, pendekatan pembelajaran yang digunakan disesuaikan dengan kurikulum 2013 yang digunakan saat ini yaitu dengan pendekatan ilmiah. Kemendikbud (2013) saat ini telah memberlakukan kurikulum baru yaitu kurikulum 2013 yang berbasis pendekatan ilmiah (scientific approach) yaitu pendekatan pembelajaran yang berpusat pada peserta didik. Langkah-langkah pembelajaran menggunakan pendekatan ilmiah yaitu mencari informasi melalui pengamatan, bertanya, melakukan percobaan, menganalisis data dan menarik kesimpulan.

Hasil penelitian yang dilakukan Marjan dkk. (2014) menunjukkan bahwa dengan menerapkan pendekatan ilmiah dalam proses pembelajaran dapat meningkatkan hasil belajar siswa dan keterampilan proses sains, hal ini disebabkan bahwa dalam pendekatan ilmiah siswa mengonstruksi sendiri pengetahuannya tentang konsep-konsep yang dipelajari. Melalui pendekatan ilmiah pembelajaran menjadi berpusat pada siswa (student centered), siswa 
diharapkan dapat terlibat secara maksimal dalam proses pembelajaran dan siswa dapat menemukan dan membangun sendiri konsep-konsep pembelajaran. Penelitian lain dilakukan oleh Novianti dkk. (2014) bahwa dengan pendekatan ilmiah dapat meningkatkan aktivitas dan hasil belajar siswa.

Dalam mengaplikasikan pendekatan ilmiah dalam pembelajaran, model pembelajaran yang digunakan pada penelitian ini yaitu inkuiri terbimbing dan project based learning. Suryani dan Agung (2012: 119) menyatakan bahwa Inkuiri (Inquiry) berasal dari kata "to inquire" yang maknanya adalah ikut serta, atau terlibat, dalam mengajukan suatu pertanyaan, me-lakukan penyelidikan dan mencari informasi serta pembelajaran inquiry bertujuan untuk melatih bagaimana sis-wa membangun kecakapan berpikir terkait dengan proses-proses berpikir reflektif.

Model pembelajaran project based learning, menuntut siswa untuk membuat sebuah produk hasil dari pembelajaran yang telah dilakukan, kemudian produk tersebut dipresentasikan di depan kelas. Hal ini mendorong siswa lebih kreatif, meningkatkan kolaborasi dan dapat memecahkan masalah sendiri.

Setelah materi pembelajaran selesai, untuk mengukur kemampuan siswa dapat dilihat dari hasil belajar yang ia peroleh. Hasil belajar digunakan untuk mengetahui sejauh mana siswa dapat memahami suatu materi pembelajaran. Hasil belajar siswa dapat diukur dengan taksonomi bloom dalam ranah kognitif yang telah direvisi Anderson \& Krathwohl (2001) yaitu mengingat $(\mathrm{C} 1)$, memahami atau me-ngerti (C2), menerapkan (C3), menganalisis (C4), mengevaluasi (C5), dan menciptakan (C6). Keenam aspek kognitif tersebut diprediksi dapat meningkat dengan pembelajaran blended learning.

Berdasarkan ulasan-ulasan di atas, peneliti mencoba melakukan penelitian menggunakan blended learning berbasis LMS dengan pendekatan ilmiah yang bertujuan untuk mendeskripsikan dampak blended learning pada materi fluida dinamis terhadap hasil belajar siswa.

\section{METODE PENELITIAN}

Populasi penelitian, yaitu seluruh siswa kelas XI di salah satu SMA di Bandarlampung pada semester genap tahun ajaran 2017/2018. Penelitian ini merupakan penelitian dengan metode Quasi Experimental Design dengan jenis pretest-posstest control grup design.

Tabel 1. Desain Eksperimen

\begin{tabular}{cccc}
\hline Kelas & $\begin{array}{c}\text { Pre- } \\
\text { test }\end{array}$ & Perlakuan & $\begin{array}{c}\text { Post- } \\
\text { test }\end{array}$ \\
\hline Eksperimen & $\mathrm{O}_{1}$ & $\mathrm{X}_{1}$ & $\mathrm{O}_{2}$ \\
Kontrol & $\mathrm{O}_{3}$ & $\mathrm{X}_{2}$ & $\mathrm{O}_{4}$ \\
\hline
\end{tabular}

Penelitian ini menggunakan dua kelas yaitu kelas kontrol dan eksperimen. Kelas kontrol diberikan pembelajaran menggunakan metode ceramah dan kelas ekperimen diberikan perlakuan dengan pembelajaran blended learning berbasis LMS dengan pendekatan ilmiah. Pada kelas eksperimen penelitian ini, pendekatan ilmiah dibagi pada saat pembelajaran online dan pembelajaran tatap muka. Pada pembelajaran online menggunakan LMS berupa schoology, dimana saat pembelajaran online siswa melakukan kegiatan mengamati, merumuskan masalah dan mengajukan hipotesis berdasarkan video pembelajaran yang disajikan. Selanjutnya, pada pembelajaran tatap muka, siswa melakukan sebuah percobaan, mengumpulkan da- 
ta, menganalisis data dan menarik kesimpulan.

Penelitian ini memiliki dua variabel, yaitu variabel bebas dan variabel terikat. Variabel bebas pada penelitian ini yaitu pembelajaran blended learning berbasis $L M S$ dengan pendekatan ilmiah. Variabel terikat pada penelitian ini adalah hasil belajar siswa. Instrumen yang digunakan pada penelitian ini adalah Rencana Pelaksanaan Pembelajaran (RPP), Lembar Kerja Peserta Didik (LKPD), handout (bahan ajar cetak yang berisi materi lengkap dan contoh soal beserta pembahasannya), schoology, dan tes berbentuk pilihan jamak beralasan yang digunakan untuk mengukur hasil belajar siswa. Soal tes ini digunakan saat pretest dan posttest.

Data yang diperoleh dalam penelitian ini adalah data hasil belajar siswa ranah kognitif yang ditunjukkan pada proses pembelajaran. Data yang di-peroleh kemudian dianalisis dengan uji $N$-Gain, uji normalitas, uji homogenitas, dan uji Independent Sample TTest.

Pengambilan keputusan uji normalitas dikatakan berdistribusi normal jika pada Kolmogorov Smirnov nilai sig > 0.05 dan data yang tidak terdistribusi normal memiliki nilai sig $\leq$ 0.05. Uji homoge-nitas dilakukan untuk mengetahui sama atau tidaknya varian dari populasi. Jika nilai signifikasi $\leq$ 0,05 , maka dikatakan bahwa varian dari dua kelompok popu-lasi data adalah tidak sama. Setelah di-lakukan uji homogenitas, dilakukan uji Independent Sample T-Test untuk mengetahui ada atau tidaknya perbedaan rata-rata antara dua kelompok sampel yang tidak berhubungan. Pedoman Independent Sample T-Test berdasarkan nilai signifikansi atau nilai probabilitas:

(1) Jika nilai signifikansi atau nilai probabilitas > 0,05 maka $\mathrm{H}_{0}$ diterima; (2) Jika nilai signifi-kansi atau nilai probabilitas $\leq 0,05$ maka $\mathrm{H}_{0}$ ditolak.

\section{HASIL PENELITIAN}

Penelitian mengenai efektivitas blended learning pada materi fluida dinamis terhadap hasil belajar siswa dilaksanakan di salah satu SMA di Bandarlampung. Proses pembelajaran berlangsung selama 3 kali tatap muka dengan alokasi waktu 2 jam pelajaran yang terdiri atas 45 menit per jam pelajaran. Sebelum melakukan kegiatan tatap muka pada kelas eksperimen, seluruh siswa sudah melaksanakan pembelajaran online terlebih dahulu di schoology. Aktivitas pada pembelajaran online sebelum pertemuan tatap muka dilakukan untuk membahas materi dan kegiatan percobaan yang akan dilakukan pada saat pertemuan tatap muka.

Pada penelitian ini, kelas eksperimen menggunakan kelas XI IPA 5 di salah satu SMA di Bandarlampung. Pelaksanaan pembelajaran pada kelas ini diikuti oleh 33 siswa dan dilaksanakan dengan menyesuaikan jadwal pelajaran fisika di sekolah. Sementara itu, kelas kontrol menggunakan XI IPA 4 yang terdiri dari 35 siswa, dengan keseluruhan proses pembelajaran sebanyak tiga kali pertemuan. Instrumen tes hasil belajar siswa pada penelitian ini, terlebih dahulu diuji validitas dan reliabilitas pada setiap butir soalnya untuk mengetahui layak atau tidaknya soal tersebut digunakan untuk penelitian. Dari 24 butir soal yang diujikan, terdapat 23 butir soal valid, yang mewakili semua indikator dan ada 1 butir soal yang dinyatakan tidak valid. Soal yang akan digunakan untuk penelitian sebanyak 20 soal. Data hasil uji reliabilitas menunjukkan bahwa instrumen soal yang akan digunakan bersifat reliabel.

Perbedaan rata-rata kemampuan hasil belajar siswa kelas eksperimen dan kontrol secara signifikan dapat dilihat dari nilai $\mathrm{N}$-Gain setelah diberi 
perlakuan. Rata-rata $N$-Gain pada kelas eksperimen yang menggunakan blended learning berbasis LMS dengan pendekatan ilmiah adalah 0,72 lebih tinggi daripada rata-rata $\mathrm{N}$-Gain kelas kontrol yang menggunakan metode ceramah yaitu 0,49 . Persentase perolehan nilai rata-rata $N$-Gain hasil belajar siswa disajikan pada Gambar 1 .

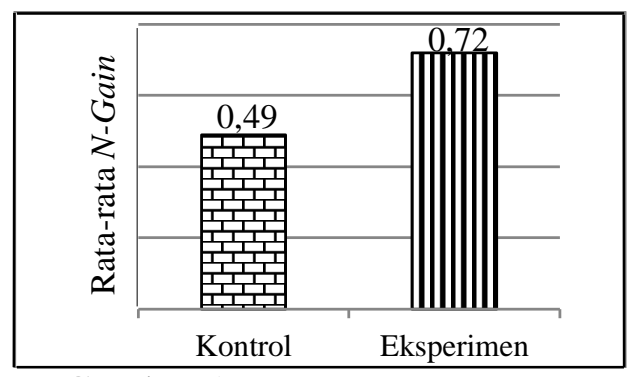

Gambar 1. Rata-rata $N$-Gain

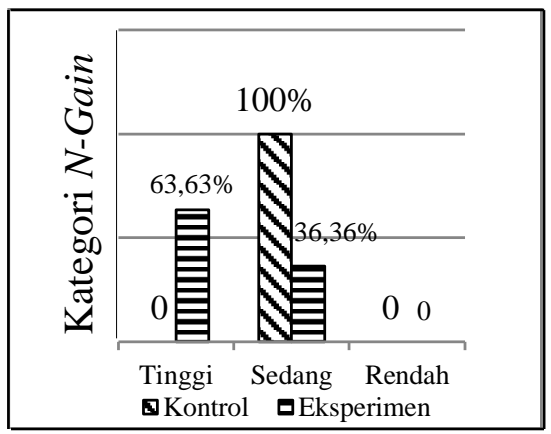

Gambar 2. Kategori $N$-Gain

Nilai rata-rata hasil belajar siswa Sig. (2-tailed) lebih besar dari 0,05 yaitu 0,20 untuk kelas eksperimen dan 0,09 untuk kelas kontrol. Hasil uji tersebut disimpulkan bahwa data nilai hasil belajar dari kelas eksperimen dan kelas berdistribusi normal.

Data hasil uji homogenitas diperoleh nilai sig. dari kesamaan varian dengan nilai signifikasi sebesar 0,99 . Ketika nilai sig. lebih besar dari 0,05 maka berdasarkan pada pengambilan uji hipotesis dapat disimpulkan bahwa kedua kelas eksperimen dan kontrol memiliki varian yang sama. Selanjutnya dilakukan uji Independent Sample T-test.

Tabel 2 menjelaskan hasil pengujian hipotesis Independent Sample Ttest. Nilai $-\mathrm{t}_{\text {hitung }}<\mathrm{t}_{\text {tabel }}$ adalah $-12,654$ $<2,26$ dan signifikansi $0,000<0,05$ maka dapat disimpulkan bahwa $\mathrm{H}_{1}$ diterima. Berdasarkan hasil pengujian tersebut, maka dapat di-simpulkan bahwa terdapat perbedaan peningkatan hasil belajar antara siswa yang belajar menggunakan blended learning berbasis LMS dengan pendekatan ilmiah dengan siswa yang belajar menggunakan metode ceramah. Hal ini berarti terdapat pengaruh yang signifikan penggunaan blended learning berbasis LMS dengan pendekatan ilmiah pada materi fluida dinamis terhadap hasil belajar ranah kognitif siswa.

\section{PEMBAHASAN}

Hasil perhitungan diketahui bahwa rata-rata hasil belajar siswa

Tabel 1. Hasil Uji Normalitas Skor $N$-Gain Hasil Belajar Siswa

\begin{tabular}{|c|c|c|c|c|}
\hline \multirow[b]{2}{*}{ Para-meter } & \multicolumn{2}{|c|}{ Kelas Eksperimen } & \multicolumn{2}{|c|}{ Kelas Kontrol } \\
\hline & $\begin{array}{c}\text { Pre- } \\
\text { test }\end{array}$ & $\begin{array}{r}\text { Post- } \\
\text { Test }\end{array}$ & $\begin{array}{c}\text { Pre- } \\
\text { test }\end{array}$ & $\begin{array}{l}\text { Post- } \\
\text { Test }\end{array}$ \\
\hline Jumlah Siswa. & 33 & 33 & 35 & 35 \\
\hline Rata-rata & 25,9 & 79,5 & 24,5 & 61,4 \\
\hline $\begin{array}{l}\text { Nilai. } \\
\text { Tertinggi }\end{array}$ & 35 & 90 & 30 & 70 \\
\hline $\begin{array}{l}\text { Nilai. } \\
\text { Terendah }\end{array}$ & 15 & 75 & 10 & 55 \\
\hline$N$-Gain. & \multicolumn{2}{|c|}{0,72} & \multicolumn{2}{|c|}{0,49} \\
\hline Asymp. Sig (2-tailed). & \multicolumn{2}{|c|}{0,20} & \multicolumn{2}{|c|}{0,09} \\
\hline
\end{tabular}


pada kelas eksperimen saat posttest adalah 79,54 lebih besar daripada ratarata hasil belajar pada kelas kontrol saat posttest yaitu 61,42 .

Perbedaan rata-rata kemampuan hasil belajar siswa kelas eksperimen dan kelas kontrol secara signifikan dapat dilihat dari $N$-Gain, dimana rata- rata $N$-Gain hasil belajar menggunakan blended learning ber-basis LMS dengan pendekatan ilmiah lebih tinggi dibandingkan rata-rata $N$-Gain hasil belajar menggunakan metode ceramah. $\mathrm{N}$-Gain hasil belajar siswa diperoleh dari data hasil penggunaan instrumen tes pretest dan posttest.

Tabel 2. Hasil Uji Independent Sample T-test Hasil Belajar Siswa

\begin{tabular}{|c|c|c|c|c|c|}
\hline \multicolumn{3}{|c|}{ Levene's For Of Test Equality Variances } & \multicolumn{3}{|c|}{ T-Test for Equality of Means } \\
\hline & $\mathrm{F}$ & Sig. & $\mathrm{T}$ & $\mathrm{df}$ & $\begin{array}{l}\text { Sig. }(2- \\
\text { tailed })\end{array}$ \\
\hline Equal Var. Assumed & 0,000 & 0,996 & $-12,654$ & 66 & 0,000 \\
\hline $\begin{array}{l}\text { Equal Var. Not } \\
\text { Assumed }\end{array}$ & & & $-12,644$ & 65,498 & 0,000 \\
\hline
\end{tabular}

Hasil perhitungan diketahui ratarata $N$-Gain kelas eksperimen sebesar 0,72 dengan kategori tinggi, sedangkan hasil perhitungan rata-rata $N$-Gain kelas kontrol sebesar 0,49 dengan kategori sedang. Berdasarkan hasil perhitungan diketahui bahwa pada kelas eksperimen siswa yang memperoleh kategori tinggi sebanyak 23 siswa $(63,63 \%)$, kategori sedang 12 siswa $(36,36 \%)$, dan 0 siswa memperoleh kategori rendah. Sedangkan pada kelas kontrol, siswa yang memperoleh kategori tinggi adalah 0 siswa, ketegori sedang adalah 35 siswa $(100 \%)$, dan siswa yang mendapatkan kategori rendah adalah 0 siswa.

Setelah dilakukan pengujian Independent Sample T test didapatkan nilai signifikansi antara kelas eksperimen dan kelas kontrol, Asymp. Sig.(2-tailed) pada uji t adalah sebesar 0,000 kurang dari 0,05, maka dapat disimpulkan bahwa $\mathrm{H}_{1}$ diterima. Berdasarkan hasil pengujian tersebut, maka dapat disimpulkan bahwa terdapat perbedaan peningkatan hasil belajar antara siswa yang belajar menggunakan blended learning berbasis LMS dengan pendekatan ilmiah dengan siswa yang belajar menggunakan metode cera- mah. Hal ini berarti terdapat pengaruh yang signifikan penggunaan blended learning berbasis LMS dengan pendekatan ilmiah pada materi fluida dinamis terhadap hasil belajar ranah kognitif siswa.

Pada penelitian ini, pendekatan pembelajaran yang digunakan disesuaikan dengan kurikulum 2013 yang digunakan saat ini yaitu dengan pendekatan ilmiah. Jenis blended learning yang digunakan pada penelitian ini yaitu blended learning berbasis LMS dengan pendekatan ilmiah dengan desain pembelajaran secara online-tatap muka. Pada pembelajaran online menggunakan LMS berupa schoology. Pada pembelajaran tatap muka, siswa melakukan kegiatan percobaaan atau eksperimen dengan kelompok kecil yang berjumlah 5 orang. Teori belajar yang mendasari hal ini adalah collaborative learning. Collaborative learning adalah salah satu bentuk pembelajaran yang berdasarkan faham kontruksivisme dari Piaget.

Kelebihan dari pembelajaran blended learning berbasis LMS dengan pendekatan ilmiah adalah pada setiap kegiatan tatap muka, siswa melakukan 
percobaan atau eksperimen sehingga membuat siswa dapat aktif bekerja sama dalam kelompok, berpikir kritis dalam mengonstruksikan pengetahuannya melalui pengamatan langsung pada obyek yang akan diamati, serta siswa dapat menyimpulkan data berdasarkan informasi dan fakta-fakta yang ditemukan sendiri.

Kelebihan pembelajaran dengan pendekatan ilmiah dapat menghadirkan kondisi pembelajaran yang mendorong siswa untuk mencari tahu informasi dari berbagai sumber melalui observasi, sehingga siswa dapat lebih aktif dan terlibat dalam proses pembelajaran. Hasil ini didukung oleh penelitian yang dilakukan Marjan dkk. (2014) menunjukkan bahwa dengan menerapkan pendekatan ilmiah dalam proses pembelajaran dapat meningkatkan hasil belajar siswa dan keterampilan proses sains, hal ini disebabkan bahwa dalam pendekatan ilmiah siswa mengonstruksi atau menemukan dan mengonstruksi sendiri pengetahuannya tentang konsepkonsep yang dipelajari. Penelitian lain dilakukan oleh Fauziah dkk. (2013) yang menyatakan bahwa melalui pendekatan ilmiah menjadikan siswa lebih mudah mempelajari materi karena permasalahan yang digunakan adalah permasalahan sehari-hari dan solusi dari permasalahan didapatkan melalui percobaan dan dengan adanya interaksi aktif antara siswa dengan siswa dan interaksi siswa dengan guru. Hal ini sesuai dengan hasil penelitian yang dilakukan Irawan \& Hasanah.

Thaib dkk. (2016) menyatakan bahwa teori belajar yang mendasari model pembelajaran blended learning adalah teori belajar konstruktivisme (individual learning) dari Piaget, Kognitif dari Brunner, Gagne dan Blooms, serta lingkungan belajar sosial dari Vygotsky. Kelebihan lain pada pe- nelitian blended learning berbasis LMS dengan pendekatan ilmiah ini, siswa membangun pengetahuannya sendiri dengan melakukan percobaan langsung pada kegiatan tatap muka dan belajar mandiri melalui pembelajaran online dengan schoology.

Melalui pembelajaran online dengan schoology, siswa dapat meningkatkan kemampuan dalam megamati fenomena yang berhubungan dengan fluida dinamis melalui video pembelajaran yang disediakan, siswa dapat berdiskusi dengan guru maupun siswa lain melalui kolom diskusi yang tersedia, sehingga jika ada materi yang kurang dipahami saat pembelajaran di kelas siswa dapat langsung bertanya di kolom diskusi tersebut dan dapat mengemukakan pendapatnya mengenai materi yang sedang dibahas. Guru juga dapat dengan mudah memantau aktivitas siswa dan pendapat yang diutarakan siswa pada kelas online. Pembelajaran online juga membantu mengatasi kendala belajar di sekolah salah satunya yaitu kekurangan waktu belajar di dalam kelas.

Carman (2005) menyatakan bahwa ada lima kunci untuk melaksanakan pembelajaran blended learning salah satunya yaitu dengan self paced learning. Kelebihan lain pada penelitian ini adalah menerapkan self paced learning, yaitu kegiatan mengkombinasikan pembelajaran mandiri yang memungkinkan peserta belajar kapan saja, dimana saja dengan menggunakan bahan belajar bersifat teks maupun multimedia.

Bentuk media pembelajaran pada schoology yaitu berupa video, audio dan gambar sehingga dapat menarik minat siswa untuk belajar dan memudahkan siswa untuk memahami materi pembelajaran yang agak rumit seperti materi fisika fluida dinamis. Penelitian yang dilakukan oleh Suana 
dkk. (2017) menunjukkan bahwa pembelajaran blended learning yang dilaksanakan melalui schoology dapat meningkatkan minat dan motivasi belajar siswa, serta dapat mengembangkan keterampilan TIK siswa. Selain itu, pemberian latihan soal pada schoology membuat siswa dapat latihan secara mandiri untuk dapat meningkatkan pemahaman konsep siswa dan keterampilan pemecahan masalah. Hasil penelitian yang dilakukan oleh Hasanah dkk. (2016) menunjukkan bahwa e-learning dengan schoology sangat menarik, mudah, sangat bermanfaat dan efektif untuk digunakan sebagai suplemen pembelajaran karena $91 \%$ siswa mencapai KKM untuk aspek kognitif dan 100\% siswa mencapai KKM untuk aspek afektif dan psikomotor.

Jenis diskusi online di schoology yang digunakan pada penelitian ini adalah diskusi asynchronous yaitu diskusi yang dapat dilakukan kapan saja, artinya siswa tidak ditentukan kapan mereka harus melakukan pembelajaran online. Ausburn (2004) menyatakan bahwa diskusi asynchronous lebih direkomendasikan agar siswa dapat belajar sesuai dengan kecepatan belajarnya. Diskusi asynchronous memiliki beberapa kelebihan diantaranya yaitu menurut Meyer (2007) siswa lebih banyak waktu untuk berpikir tentang topik yang sedang dipelajari, siswa dapat menyelidiki lebih lanjut tentang topik tersebut dan siswa dapat memperoleh lebih banyak informasi, selain itu siswa juga dapat berinteraksi dengan pengajar kapan pun mereka punya waktu (Aspden \& Helm, 2004). Jenis diskusi ini juga tidak memberatkan siswa yang tinggal di daerah yang memiliki jaringan internet yang kurang baik, sehingga siswa dapat menyesuaikan waktu diskusi ketika akses internet cepat dan stabil.

Setelah melakukan pembelajaran menggunakan blended learning berbasis $L M S$ dengan pendekatan ilmiah, siswa lebih aktif dan berantusias dalam pembelajaran online yakni melalui $e$ learning dengan schoology. Husamah (2014: 4) menyatakan bahwa pemanfaatan e-learning sangat diunggulkan dibanding dengan pembelajaran ceramah secara tatap muka, karena dengan e-learning, pembelajaran dapat lebih terbuka, fleksibel dan dapat terjadi kapan saja, dimana saja, dengan siapa saja. Siswa dapat belajar atau mengkaji pelajaran setiap saat diperlukan, dan bila siswa memerlukan tambahan informasi yang berkaitan dengan bahan yang dipelajarinya, siswa dapat mengakses pada pembelajaran online secara lebih mudah. Hal ini merubah peran siswa dari yang biasanya pasif menjadi aktif. Dapat dikatakan bahwa e-learning merupakan solusi bagi pendidik untuk menerapkan konsep belajar jarak jauh dengan menggunakan TIK dan internet dalam meningkatan pembelajaran.

Siswa dapat mengakses schoology melalui komputer, laptop maupun smartphone. Maraknya penggunaan smartphone oleh siswa, mendorong adanya inovasi pembelajaran yang baru dan menarik. Berdasarkan hal ini, mobile learning ini dapat digunakan pada saat pembelajaran online dengan schoology. Pada penelitian ini siswa dapat dengan mudah mengikuti pembelajaran online dengan smart-phonenya sendiri karena mudah di-bawa kemana saja dengan ukuran kecil dan ringan dibandingkan PC (Personal Computer) atau laptop. Siswa juga dapat mengakses LKPD dan handout yang berupa softfile di schoology melalui smartphone-nya. 
Keberhasilan suatu proses pembelajaran ditunjukkan dengan hasil belajar siswa. Pada penelitian ini dapat dibuktikan bahwa penggunaan blended learning berbasis LMS dengan pendekatan ilmiah berpengaruh pada hasil belajar ranah kognitif siswa. Rata-rata hasil belajar siswa kelas eksperimen yang menggunakan blended learning berbasis $L M S$ dengan pendekatan ilmiah lebih tinggi daripada kelas kontrol yang menggunakan metode ceramah. Hal ini didukung oleh pe-nelitian yang dilakukan Sjukur (2012) menunjukkan hasil yaitu siswa yang mengikuti pembelajaran dengan blended learning memiliki peningkatan motivasi dan prestasi belajar yang lebih tinggi dibandingkan siswa yang di-ajarkan menggunakan metode pem-belajaran ceramah.

Penelitian lain dilakukan oleh Purnomo dkk. (2016) menunjukkan bahwa dengan menerapkan blended learning dengan desain online-tatap muka, siswa seluruhnya mengikuti proses pembelajaran dengan baik yang ditunjukkan dengan nilai dan keaktifan di kelas. Hal ini sejalan dengan penelitian Zaka (2013) bahwa pembelajaran blended learning dapat meningkatkan keterlibatan siswa dan mengembangkan keterampilan TIK siswa.

Selain memiliki kelebihan pada pembelajaran blended learning berbasis $L M S$ dengan pendekatan ilmiah, pembelajaran ini juga memiliki kendala. Salah satu kendala yang dialami siswa yaitu pada saat pembelajaran online ketika siswa diminta mengumpulkan tugas diskusi di schoology, selalu ada beberapa siswa yang terlambat mengumpulkan tugas. Kendala yang dihadapi siswa dalam mengumpulkan tugas yaitu ada beberapa siswa yang tidak memiliki smartphone atau laptop dan beberapa siswa memiliki akses internet yang lambat dan tidak stabil.

Selain itu, produk yang digunakan pada penelitian ini yaitu RPP, LKPD, handout dan schoology dibuat oleh Nurhayati dkk. (2018). Produk yang dikembangkan ini sudah diuji validasi dan diuji kepraktisan oleh dua orang ahli fisika dan tiga orang guru fisika SMA yang menunjukkan bahwa kualitas yang sangat baik dan layak digunakan. Perangkat yang dikembangkan dikatakan sangat praktis karena dapat menghemat waktu dengan beberapa tahap pendekatan ilmiah dilakukan diluar waktu pembelajaran (pada kelas online), guru dapat dengan mudah memantau setiap jawaban atau pendapat siswa yang diutarakan pada kelas online, dan siswa dapat dengan mudah berlatih soal yang berbeda-beda setiap kali pengerjaan soal sehingga guru tidak perlu berkali-kali membuat soal baru dan menilai hasil uji siswa.

Disamping itu, terdapat kekurangan produk yang dibuat oleh Nurhayati dkk. (2018) yaitu ukuran video pembelajaran berukuran besar sehingga proses pengunggahan video di schoology membutuhkan waktu yang lama dan ada satu video yang tidak dapat diunggah di schoology. Solusi permasalahan ini yaitu siswa hanya diberikan link videonya saja di schoology.

\section{SIMPULAN}

Berdasarkan data hasil penelitian dan pembahasan, dapat disimpulkan bahwa pembelajaran menggunakan blended learning berbasis LMS dengan pendekatan ilmiah dapat meningkatkan hasil belajar pada ranah kognitif yang ditunjukkan oleh perbedaan rata-rata nilai $N$-Gain pada kelas eksperimen yaitu 0,72 dengan kategori peningkatan hasil belajar yang tinggi dan 0,49 untuk kelas kontrol dengan kategori sedang. 


\section{DAFTAR RUJUKAN}

Amiroh. 2013. Antara Schoology, Moddle dan Edmodo. [Online] tersedia di http://amiroh.web.id/ antara-moodle-edmodo-dan schoology/. Diakses pada tanggal 30 September 2017.

Anderson, L. W., \& Krathwohl, D. R. 2001. A Taxonomy for Learning, Teaching, and Assesing: A Revision of Bloom's Taxonomy of Educatioanl Objectives. New York: Addison Wesley Long man, Inc.

Ausburn, L. J. 2004. Course Design Elements Most Valued By Adult Learners In Blended Online Educaton Environments: An American Perspective. Educatio nal Media International, 41 (4), 327-337.

Aspden, L., \& Helm, P. (2004). Making the connection in a blended learning environment. Educational Media International, 41 (3), 245-252.

Carman, J. M. 2005. Blended Learning Design: Five Key Ingredients. [Online] tersedia di http://agilant learning.com/pdf Blended Learn ingDesign.pdf. Diakses pada tanggal 1 Oktober 2017.

Fauziah, R., Abdullah, A. G., \& Hakim, D. L. 2013. Pembelajaran Saintifik Elektronika Dasar Berorientasi Pembelajaran Ber basis Masalah. Invotec, 9 (2), 165-178.

Fitriyadi, H. 2013. Integrasi Teknologi Informasi Komunikasi Dalam Pendidikan: Potensi Manfaat, Masyarakat Berbasis Pengeta huan, Pendidikan Nilai, Strategi Implementasi Dan Pengem bangan Profesional. Jurnal Pendidikan Teknologi dan Kejuruan, 21 (3), 269-284.
Hasanah, N., Suyanto, E., \& Suana, W. 2016. E-Learning dengan Schoology sebagai Suplemen Pembelajaran Fisika Materi Elastisitas dan Hukum Hooke. Jurnal Pembelajaran Fisika, 4 (2), 71-81.

Husamah. 2014. Pembelajaran Bauran (Blended Learning). Jakarta:

Prestasi Pustaka.

Irawan, F., \& Hasanah, R. 2014. Pengaruh Penerapan Model Pembelajaran Problem Based Learning (PBL) Dengan Pendekatan Saintifik Pada Materi Kalor Dan Perubahan Wujud Zat Terhadap Hasil Belajar Siswa Kelas X Sman 15 Surabaya. Jurnal Inovasi Pendidikan Fisika (JIPF), 3 (3), 86-90.

Kementrian Pendidikan dan Kebudayaan. 2013. Implementasi Kurikulum $2013 \quad$ Konsep Pendekatan Scientific. Jakarta: Departemen Pendidikan dan Kebudayaan.

Marjan, J., Arnyana, I. B. P., \& Setiawan, I. G. A. N. 2014. Pengaruh Pembelajaran Pende katan Saintifik Terhadap Hasil Belajar Biologi dan Keteram pilan Proses Sains Siswa MA Mu'allimat NW Pancor Selong Kabupaten Lombok Timur Nusa Tenggara Barat. E-Journal Program Pascasarjana Univer sitas Pendidikan Ganesha, 4 (1), 1-12.

Mosa, E. 2006. Puntoedu: A Blended E-Learning Model. Current Developments in TechnologyAsisted Education, 6 (4), 17441749.

Meyer, K. A. 2007. Student perceptions of face to face and online discussions: The 
advantage goes to ... Journal of Asynchronous Learning

Networks, 11 (4), 53-69.

Munir. 2009. Pembelajaran Jarak Jauh Berbasis Teknologi Informasi dan Komunikasi. Bandung: Alfabeta.

Novianti, W. E., Ertikanto, C., \& Wahyudi, I. 2014. Pengaruh Aktivitas Terhadap Hasil Belajar IPA Melalui Scientific Approach Dengan Bantuan BSE. Jurnal Pembelajaran Fisika, 2 (4), 145157.

Nurhayati, V., Suyanto, E., \& Suana, W. 2018. Desain Perangkat Blended Learning Berbantuan Learning Management System Pada Materi Fluida Dinamis. Jurnal Pendidikan Fisika, 6 (1), 21-33.

Poon, J. 2013. Blended learning: An institutional approach for enhancing students' learning experiences. Journal of online learning and teaching, 9 (2), 271-289.

Purnomo, A., Rahmawati, N., \& Aristin, N. F. 2016. Pengembangan Blended Learn ing Pada Generasi Z. Jurnal Teori dan Praktis Pembelajaran IPS, 1 (1), 70-76.

Sjukur, S. B. 2012. Pengaruh Blended Learning Terhadap Motivasi Belajar dan Hasil Belajar Siswa
Tingkat SMK. Jurnal Pendidikan Vokasi, 2 (3), 368-378.

Suana, W., Maharta, N., \& Nyeneng, I. D. P., \& Wahyuni, S. 2017. Design And Implementation Schoology-Based Blended Learning Media For Basic Physics I Course. Jurnal Pendidikan IPA Indonesia, 6 (1), 170-178.

Suryani, N. \& Agung, L. 2012. Strategi Belajar Mengajar. Yogyakarta: Ombak.

Thaib, D., Wahyudin, D., Rahmawati, Y., \& Riyana, C. 2016. Studi Analisis Kebutuhan Terhadap Pengembangan Model Blended Learning Pada Sistem Pendidikan Jarak Jauh Untuk Meningkatkan Kompetensi Lulusan. Jurnal Pendidikan Dasar, 8 (2), 107-125.

Utami, R. P., Rosidin, U., \& Wahyudi, I. 2017. Pengaruh Penggunaan ELearning Dengan Schoology Materi Gravitasi Newton Terhadap Hasil Belajar Siswa. Jurnal Pembelajaran Fisika, 5 (2), 81-91.

Zaka, P. 2013. A Case Study Of Blended Teaching And Learning In A New Zealand Secondary School, Using An Ecological Framework. Journal of Open, Flexible And Distance Learning, 17 (1), 24-40. 